\title{
An initial study of the Internal Validity of the Portuguese Adaptation of the Marital Social-Skills Inventory
}

\author{
Adaptação do Inventário de Habilidades \\ Sociais Conjugais em Portugal: estudo \\ preliminar de validação
}

Joyce Cristina dos Santos AGUIAR ${ }^{1}$ iD) 0000-0002-5462-4914

Marisa MATIAS ${ }^{1}$ iD) 0000-0002-5755-5096

Elizabeth Joan BARHAM² ID 0000-0002-7270-4918

Anne Marie Germaine Victorine FONTAINE ${ }^{1}$ ID 0000-0001-9232-8692

Zilda Aparecida Pereira DEL PRETTE² (iD) 0000-0002-0130-2911

\begin{abstract}
In this study, we evaluated the internal structure of the Portuguese version of the Marital Social-Skills Inventory. After adapting the language of the inventory from Brazilian to European Portuguese, it was tested with 540 Portuguese respondents (20 to 70 years of age), who had been in a stable relationship for at least one year. A principal components analysis $(n=310)$ suggested that the internal structure includes four dimensions: Expressiveness, Self-affirmation, Self-control and Assertive Conversation. This structure was tested using a confirmatory analysis $(n=230)$, yielding satisfactory indicators of overall adjustment. Cronbach's alpha values for the first three dimensions indicated good internal consistency. The internal structure of the Portuguese version of the Marital Social-Skills Inventory-Villa \& Del-Prette is coherent with the original structure, and psychometrically sound for the evaluation of marital social-skills among Portuguese couples. Thus, this instrument can be a useful tool in assessment and intervention work with couples.
\end{abstract}

Keywords: Conjugality; Cultural adaptation; Marital Social-Skills Inventory; Social skills.

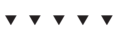

1 Universidade do Porto, Centro de Psicologia, Faculdade de Psicologia e Ciências da Educação. R. Dr. Alfredo Allen, 4200-135, Porto, Portugal. Correspondência para/Correspondence to: J. AGUIAR. E-mail: <jcaguiar2@gmail.com>.

2 Universidade Federal de São Carlos, Departamento de Psicologia, Programa de Pós-Graduação em Psicologia. São Carlos, SP, Brasil.

$\mathbf{\nabla} \mathbf{\nabla} \mathbf{v}$

Como citar este artigo/How to cite this article

Aguiar, J. C. S., Matias, M., Barham, E. J., Fontaine, A. M. G. V., \& Del Prette, Z. A. P. (2018). An initial study of the Internal Validity of the Portuguese Adaptation of the Marital Social-Skills Inventory. Estudos de Psicologia (Campinas), 35(3), 275-285. http://dx.doi. org/10.1590/1982-02752018000300006 


\section{Resumo}

Este estudo teve como objetivo avaliar a estrutura fatorial de uma versão portuguesa do Inventário de Habilidades Sociais Conjugais. Após adaptação do idioma português do Brasil para o português europeu, o inventário foi aplicado em 540 portugueses (com idades entre 20 a 70 anos), que estavam a viver em conjugalidade há pelo menos um ano. A análise dos componentes principais $(n=310)$ sugeriu uma estrutura de quatro dimensões, denominadas Expressividade, Autoafirmação, Autocontrolo e Conversação Assertiva. A testagem do modelo na análise fatorial confirmatória $(n=230)$ indicou um ajustamento global aceitável. O alfa de Cronbach das três primeiras dimensões demonstrou boa consistência interna. Conclui-se que a estrutura interna da versão portuguesa do Inventário de Habilidades Sociais Conjugais-Villa \& Del-Prette é coerente com a estrutura original e psicometricamente adequada à avaliação de habilidades sociais conjugais em portugueses. Assim, o instrumento poderá ser uma útil ferramenta na avaliação e intervenção com casais.

Palavras-chave: Conjugalidade; Adaptação cultural; Inventário de Habilidades Sociais Conjugais; Habilidades sociais.

Considering the various definitions that appear in the literature, in this paper, "social skills" are defined as the set of behaviors that is necessary to deal with issues related to interpersonal relationships, in a socially competent manner (Del Prette \& Del Prette, 2014). Social skills have been extensively studied in recent decades, and Del Prette and Del Prette, in Brazil, have made notable contributions (Manolio \& Ferreira, 2011). Many researchers have sought to identify and describe classes of behaviors that make social interactions less conflictual and more satisfactory (Braz, Cômodo, Del Prette, Del Prette, \& Fontaine, 2013; Couto, Vandenberghe, Tavares, \& Silva, 2012).

In addition to identifying social skills that are important in the general population (such as paying compliments or expressing displeasure), there has been a growing interest in examining behaviors that may be important for specific segments of the population or in particular relationship contexts. One of these contexts, highly relevant to adult development, is the marital relationship. Conjugality involves particular demands for resolving conflicts and for the expression of feelings, given that this relationship involves high levels of intimacy and strong emotional intensity. As such, for a couple to deal with interpersonal demands in a satisfactory manner, each spouse must have an adequate repertoire of marital social-skills (Villa, Del Prette, \& Del Prette, 2007).

Although various studies show an association between indicators of the quality of the spousal relationship and social skills (Capafóns \& Sosa, 2015; Figueiredo, 2005; Sardinha, Falcone, \&
Ferreira, 2009), validated instruments that can be used to assessing marital social-skills are still scarce. Given this scenario, the objective of the present study was to test, in Portugal, an instrument that is used to evaluate marital social skills, developed by Villa and Del Prette, Z. A. P. (2012), in Brazil.

\section{Marital social skills}

Based on the Minimal Marital Therapy model, developed by Gottman and Rushe (1995), it is possible to list at least five classes of social behaviors that are of critical importance to a satisfactory marital relationship: (1) when faced with a conflict, calm yourself and identify your own and your partner's physiological alterations; (2) listen in a non-defensive manner; (3) validate your partner's emotions, using empathic responses; (4) avoid interaction patterns that involve complaintscriticisms, defensive-disdaining behaviors and disregard-distancing responses; and (5) demonstrate sensitivity to your partner's style of persuasion and negotiation, to avoid prolonged arguments. To encompass this range of behaviors, Villa and Del Prette, Z. A. P. (2012) selected the classes of general, adult social-skills that are most important to the marital context: empathy, assertiveness, expressing positive emotions, self-monitoring, communication, and civility, which will be briefly described.

"Empathic social skills" involve showing understanding, offering support for and validating your partner's emotions. These skills permit each partner to notice the other's reactions to different events, which is of fundamental importance 
in finding ways to interact that promote the psychological wellbeing of both partners. Sardinha et al. (2009) observed a direct and statistically significant relationship between empathic skills and marital satisfaction and also with the quality of the relationship.

"Assertive social skills" refer to verbal and nonverbal behaviors that express needs, interests and opinions, allowing each spouse to inform and be informed about how to adjust their behavior, to take into consideration the other's beliefs, values and sentiments. According to Del Prette and Del Prette (2014), some of the behaviors in this class include: stating opinions, indicating agreement or displeasure, apologizing, and responding to criticism. According to these authors, skills such as these are important for maintaining the balance in a relationship, as they allow each partner to express him or herself as well as to hear the other's needs and opinions. For someone to use assertiveness with social competence, interactions that involve these skills must contribute to maintaining a constructive and positive conjugal relationship.

"Social skills for expressing positive emotions" are essential to developing an affectionate bond in the marital relationship (Villa, 2005), contributing to the emotional wellbeing of both spouses and making the relationship more affectionate and more reinforcing. In addition to verbal behaviors, the expression of these abilities frequently involves nonverbal behaviors, such as actions that show caring, positive facial expressions, and physical contact.

"Self-monitoring skills" are highlighted by Del Prette and Del Prette (2014) as the basis for all other social skills. They are defined as "metacognitive and affective-behavioral skills that affect how a person observes, describes, interprets, and regulates his or her thoughts, feelings and emotional responses to social situations"(p.62). Thus, they refer to people's capacity to observe the relationship between what they said or did, and the effects of their actions on others, permitting them to modify the situation by altering their behaviors, according to the social or relational context (Del Prette \& Del Prette, 2014). People who are attentive to the effect of their behaviors on others also tend to notice when their actions have negative impacts on their spouse. Consequently, these abilities increase the probability of more positive results for the marital relationship.

"Communicative social skills" encompass skills that are key in facilitating the couple's interactions, such as explaining their point of view, listening to their partner, sharing thoughts about daily life, among other skills. Based on a review of the literature on marriage, Féres-Carneiro and Neto (2010) highlighted the influence of communication on the couple's interaction and involvement patterns, such that conjugal adjustment reflects communication skills, together with other processes of the couple's relationship.

"Social skills involving civility", manifested through verbal behaviors of courtesy and kindness (for example, saying "please", "excuse me" and "thank you"), are related to standardized and socially accepted behaviors for establishing mutual respect, even in situations of little intimacy. This class of skills is also important in the context of marriage, since it is necessary to have verbal and nonverbal courtesy in the relationship (for example, not raising your voice and leaving pauses so your partner has the opportunity to respond). This class may be considered as complementary to the skills for expressing positive emotions (Del Prette \& Del Prette, 2014; Villa, 2005).

To evaluate the classes of conjugal socialskills described above, Villa and Del Prette, Z. A. P. (2012) developed the Inventário de Habilidades Sociais Conjugais (IHSC-Villa \& Del-Prette; Marital Social-Skills Inventory). The original version included 32 items. Based on the results of convergent validity studies (Bolsoni-Silva \& Marturano, 2010; Sardinha et al., 2009), the inventory was revised and now includes 28 items. An exploratory factor analysis of the revised instrument resulted in five dimensions: (a) Expressiveness/empathy, which includes the skills to express understanding, emotions, desires and positive opinions towards your spouse, as well as to discuss behaviors involving intimacy; (b) Assertive self-affirmation, which includes the skills to express preferences, emotions and opinions that may displease your partner, but in a way 
that minimizes negative effects; (c) Reactive selfcontrol, which includes skills to defend yourself in potentially stressful situations (for example, when one partner criticises or teases the other), controlling negative emotions that could affect the relationship; (d) Proactive self-control, which includes skills such as noticing when your spouse is upset, waiting your turn to speak, and making yourself understood, maintaining control over your emotions; and (e) Assertive Conversation, which includes confrontational skills (such as requesting the fulfilment of agreements, asking for clarification, disagreeing etc.), in the sense of guaranteeing the reciprocity of interactions that occur in the couple's relationship.

The objective of the present study was to examine some of the psychometric properties (reliability and factor validity) of the IHSC-Villa \& Del-Prette, when used with a sample of Portuguese couples, initiating the process of validating this instrument for use in Portugal. An appropriately adapted instrument could be used in both clinical and investigative work, for the evaluation of Portuguese respondents' social skills repertoire, in the marital context.

\section{Method}

\section{Participants}

The non-probabilistic, convenience sample included 540 Portuguese adults who resided in the Metropolitan Porto region, and who had been in a conjugal relationship for at least one year (Table 1). The participants were 41 years of age, on average (Standard Desviation $[S D]=10.83$ ) and had been in their marital relationship for an average of 13.5 years $(S D=10.61)$. Most of the couples $(80.0 \%)$ had at least one child, and $39.8 \%$ had a graduate studies degree (master's or doctoral degree).

\section{Instrument}

The IHSC-Villa \& Del-Prette is a 28-item instrument, using which the respondents indicate the frequency with which they present certain social
Table 1

Sample Characteristics

\begin{tabular}{|c|c|}
\hline Characteristics & Participantes ( $N=540) \%$ \\
\hline \multicolumn{2}{|l|}{ Age (in years) } \\
\hline $18-25$ & 6.6 \\
\hline $26-33$ & 20.0 \\
\hline $34-41$ & 30.7 \\
\hline $42-49$ & 17.5 \\
\hline $50-57$ & 18.1 \\
\hline 58 or over & 7.1 \\
\hline \multicolumn{2}{|l|}{ Education } \\
\hline Up to grade 12 & 22.8 \\
\hline Bachelor's degree & 37.4 \\
\hline Master's / Doctoral degree & 39.8 \\
\hline \multicolumn{2}{|l|}{ Time living together (in years) } \\
\hline $1-10$ & 51.8 \\
\hline $11-20$ & 21.0 \\
\hline $21-30$ & 18.7 \\
\hline 31 or more & 8.5 \\
\hline \multicolumn{2}{|l|}{ Number of children } \\
\hline 0 & 20.0 \\
\hline 1 & 33.7 \\
\hline 2 & 36.4 \\
\hline 3 & 8.7 \\
\hline $4-5$ & 1.2 \\
\hline \multicolumn{2}{|l|}{ Monthly family income } \\
\hline Less than $500 €$ & 2.0 \\
\hline $501-1000 €$ & 13.3 \\
\hline $1001-1500 €$ & 21.0 \\
\hline $1501-2000 €$ & 15.6 \\
\hline $2001-3000 €$ & 16.8 \\
\hline More than $3000 €$ & 12.0 \\
\hline Did not respond & 19.3 \\
\hline
\end{tabular}

skills in the context of their marital relationship. The Likert-format response-scale, has five intervals: 0 to 2 (never, or up to two times in ten situations similar to the one described in the item), 3 to 4 (three or four times in every ten occurrences of the situation), 5 to 6 (five or six times in every ten occurrences), 7 to 8 (seven or eight times in every ten occurrences), 9 to 10 (nine times out of ten, or always). This instrument can be used with people between 20 to 70 years of age, who are married or who are in a stable intimate relationship, and who have a minimum educational level of ninth grade. 
In 2009, a spelling agreement was established for the Portuguese language, leading to more similar use of written language in Brazil and Portugal. Nonetheless, there are still innumerable grammatical constructions, words and expressions that are specific to each culture and that are not used, or even understood, in the other culture. Thus, the first step in adapting the IHSC-Villa \& Del-Prette from Brazilian-Portuguese to EuropeanPortuguese, involved rewording the items to establish linguistic, lexical and cultural equivalence (Tanzer \& Sim, 1999). Three researchers, two from Portugal and one from Brazil, conducted this process. Next, content validity was assessed by verifying the relationship between each item and the skill set that it was intended to represent. To verify the clarity and sufficiency of the written instructions, 12 participants responded to questions about the operational equivalence of the inventory (Nunes \& Primi, 2010). This procedure also allowed the verification of the intelligibility, adequacy and consistency in respondents' understanding of the items.

In addition to the Portuguese version of the IHSC-Villa \& Del-Prette, the participants also provided information about their own and the couple's sociodemographic profile.

\section{Procedure}

This study was approved by the local ethics committee Comissão de Ética da Faculdade de Psicologia da Universidade do Porto (The Ethics Committee for the Psychology College of the University of Porto). Data were collected using both online and printed versions of the questionnaire. The snowball technique (when one participant invites others) was used to recruit participants in both application formats. Social network sites and the electronic mailing list for the University of Porto were used to invite professors, staff and students to participate in the online version of the study. For the printed version, contact was made through schools located in the Metropolitan Porto region, inviting teachers, auxiliary teachers and other staff members to participate. After signing the consent form, participants received written instructions and the questionnaire. As was the case for the online version, the printed questionnaires were completed without the presence of the researchers. The Statistical Package for the Social Sciences (SPSS Inc., Chicago, Illinois, United States) v21 program was used to register the information provided by the participants, both for those who responded to the online survey and for those who responded using a printed copy of the questionnaire.

\section{Results}

The first step of the data analysis involved the substitution of missing values using the Expectation-Maximization (EM) method. Next, the Mahalanobis Distance $\left(D^{2}\right)$ was calculated (Marôco, 2014), so that multivariate atypical cases (outliers) could be detected. No such cases were identified. The normality of the distribution of scores was evaluated by Examining Asymmetry (sk) and Curtosis ( $k u$ ) coefficients, considering values values of $|s k|<3$ and $|k u|<10$ as adequate, according to Kline (2011). A confirmatory factor analysis was conducted for the original five-factor structure of the IHSC-Villa \& Del-Prette, using the IBM SPSS Amos 21 (Wexford, United States). Parameters were estimated based on the correlations matrix and using the maximum likelihood method. The adjustment of the hypothesized model was evaluated according to the following criteria (Arbuckle, 2012): ratio $\chi^{2} / d f<5$, Comparative Fit Index (CFI) > 0.90, Goodness-of-Fit-Index (GFI) $>0.90$, Root Mean Square Error of Approximation $($ RMSEA $)<0.08$. The observed values for these parameters, for the five correlated factors model, were considered inadequate $\left(\chi^{2} / d f=2.76 ; C F I=0.74\right.$; $\mathrm{GFI}=0.76$; RMSEA $=0.08$ ). Items 6 ("I find it difficult to express affection towards my partner through words and gestures") and 13 ("When my partner criticizes me, I react aggressively") did not present statistically significant saturation values ( $p=0.08$ and 0.21 , respectively).

Since the originally proposed model did not present acceptable psychometric indicators, a new analysis of the data was undertaken, to finding a better-adjusted structure. Thus, the total sample 
was randomly divided in two parts, a calibration sample with 310 respondents and a validation sample with 230 respondents.

\section{Factor analyses}

The Kaiser-Meyer-Olkin (KMO $=0.855)$ and the Bartlett $\left(\chi^{2}=2582.712 ; d f=378 ; p=0.001\right)$ indexes indicated that a factor analysis was highly recommended (Tabachnick \& Fidell, 2013). To maximize the orthogonality of the factors, the main components were analyzed using the varimax rotation method.

Components with an eigenvalue greater than 1.0 were retained, in consonance with the scree plot (Marôco, 2014). For the selection of items that represent each factor, only items with a factor loading greater than .40 and with a minimum saturation difference of 0.15 between components were retained. Based on these criteria, 11 items were eliminated. The analysis yielded a fourdimensional structure with 17 items. In Table 2, all

Table 2

Social Skills Evaluated, Factor-Item Relationships, and Factor Loadings, Based on Exploratory Factor Analysis Results in Brazil and Portugal

\begin{tabular}{|c|c|c|c|}
\hline Social Skills & Factor-BR (Villa \& Del Prette, Z. A. P.) & Factor-PT ${ }^{\mathrm{a}}$ & Factor Loadings-PT \\
\hline 18. Praise your partner & F1 & - & - \\
\hline 7. Apologize & \multirow[t]{7}{*}{ Expressiveness/ Empathy } & - & - \\
\hline 20. Express wellbeing & & F1 & .84 \\
\hline 3. Accept a compliment & & - & - \\
\hline 28. Offer support & & F1 & .68 \\
\hline 1. Have an everyday conversation & & - & - \\
\hline 27. Express sexual satisfaction & & F1 & .67 \\
\hline 6. Show kindness & & - & - \\
\hline 19. Refuse a sexual invitation & \multirow{9}{*}{$\begin{array}{l}\text { F2 } \\
\text { Assertive self-affirmation Assertive }\end{array}$} & $\mathrm{F} 2$ & .57 \\
\hline 15. Express disapproval & & F2 & .57 \\
\hline 26. Express a different opinion & & - & - \\
\hline 11. Change the topic & & - & - \\
\hline 9. Request a change in behavior & & - & - \\
\hline 17. Ask for assistance & & F2 & .55 \\
\hline 2. Refuse to do something your spouse wants & & F2 & .53 \\
\hline 22. Respond to an unjust evaluation & & F2 & .72 \\
\hline 24. Show support & & $\mathrm{F} 2$ & .66 \\
\hline 13. Respond to criticism & \multirow[t]{4}{*}{ F3 Reactive self-control } & - & \\
\hline 21. Deal with teasing & & $\mathrm{F}^{*}{ }^{*}$ & .71 \\
\hline 16. Resolve shared problems & & $\mathrm{F} 1^{*}$ & .66 \\
\hline 25. Note changes in the partner's emotional state & & F3 & .66 \\
\hline 8. Calm down when your emotions are too strong & F4 & F3 & .75 \\
\hline 12. Wait your turn to speak & \multirow{2}{*}{ Proactive self-control } & F3 & .78 \\
\hline 23. Get your partner to understand you & & $\mathrm{F} 1^{*}$ & .64 \\
\hline 5. Remind your partner about agreements & F5 & F4 & .74 \\
\hline 10. Express disagreement & \multirow[t]{3}{*}{ Assertive conversation } & - & - \\
\hline 14. Ask questions & & - & - \\
\hline 4. Ask your partner to wait his or her turn to speak & & F4 & .81 \\
\hline
\end{tabular}

Note: aFactor-item relationships and factor loadings, for the current study; "Item that was excluded; "Factor-item relationship that is different from the 
items from the original scale are shown, indicating the skills evaluated and the saturation values for each item, for each dimension of the new structure. Differently from Villa and Del Prette's model, items 16, 21 and 23 presented factor loadings that were highest for the first dimension of the new model.

Next, the four-dimensional model that resulted from the exploratory factor analysis was submitted to a confirmatory factor analysis. This model yielded acceptable adjustment indexes $\left(\chi^{2} / d f=1.58 ; \mathrm{CFI}=0.93 ; \mathrm{GFI}=0.92 ; \mathrm{RMSEA}=0.05\right)$. The first dimension, called Expressivity, evaluates marital skills belonging to both the empathic skills and expression of positive emotions sets of social skills. The second, called Self-affirmation, covers the assertive skill set and evaluates the capacity to assertively ask for adjustments in the partner's behavior. The third, called Self-control, includes self-monitoring skills and evaluates the capacity to regulate one's own behaviors. Finally, the dimension called Assertive Conversation evaluates the capacity to communicate needs and preferences so as to integrate them with the partner's needs and preferences.

In Figure 1, the saturation values for the items and correlations between dimensions are presented. Scores on the Expressivity dimension were correlated with scores on the other three dimensions $(r=0.27, p=0.002 ; r=0.61, p=0.001$; and $r=0.50, p=0.001$, respectively). Self-control and Assertive Conversation were correlated only with each other $(r=0.29, p=0.004)$. The Selfaffirmation dimension presented negligible and non-significant correlations with Self-control $(r=-0.04$, $p=0.643)$ and with Assertive Conversation $(r=0.19, p=0.065)$.

The internal consistency analysis, as a measure of precision, was conducted using Cronbach's alpha, which yielded the following values for each dimension: $\alpha=0.83 ; 0.66 ; 0.69$ and 0.55 , respectively. After the rotation, the percentage of explained variance for each dimension was $19.9 \%, 13.7 \%, 12.2 \%$ and $8.8 \%$, which resulted in a total explained variance of $54.8 \%$.

\section{Discussion}

In this study, the adaptation of the IHSC-Villa \& Del-Prette for use in Portugal was described, as a first step in the overall validation process for this instrument. The original model, with five factors, was inadequate for the Portuguese context. As a result, the main components that underlie this instrument were determined using an exploratory factor analysis, followed by a confirmatory analysis to verify the new model. Based on this analysis, the original instrument was reduced to 17 items that form four dimensions: Expressivity, Self-affirmation, Self-control, and Conversation.

In addition to an initial, exploratory examination of the psychometric properties of the Portuguese adaptation of the IHSC-Villa \& DelPrette, the confirmation of the factorial structure of the instrument in an independent sample fills a gap in the literature, since its structure had not yet been tested via a confirmatory factor analysis (Villa \& Del Prette, Z. A. P., 2012). Differently from the original exploratory model, established with data from Brazilian couples, the items that evaluated reactive self-control and proactive self-control subclasses of behavior were grouped in a single factor called Selfcontrol, in the Portuguese sample. Furthermore, items 21 ("I am able to deal with my partner's jokes about me in a lighthearted manner"), 16 ("When we have problems in common to solve, we can talk and come to an agreement about what to do") and 23 ("In a situation in which my opinions conflict with my partner's, I can make him/her understand my position") had higher factorial loadings on Expressivity, which was different from the original model, in which these items belonged to the Reactive Self-Control and the Proactive Self-Control factors. This could be explained, in part, by the fact that the Portuguese participants' average age and average educational levels were a little higher than in the Brazilian sample. There is evidence in the literature about the relationship between social skills and these sociodemographic variables (Norgren, Souza, Kaslow, Hammerschmidt, \& Sharlin, 2004; Pinho, Fernandes, \& Falcone, 2011). Older people 


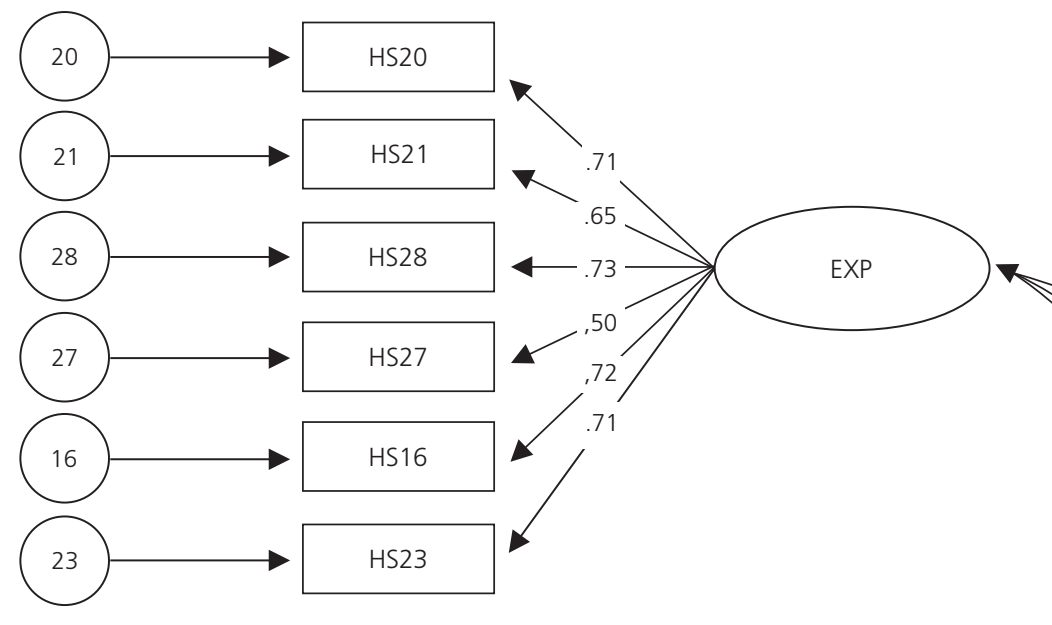


with high literacy skills tend to be more persuasive and have a greater ability to negotiate. In other words, it is possible that the capacity to express and accept different opinions may be greater among older people (who have more extensive social experience) and among people with higher educational levels (who have greater language development), which might have resulted in a different organization of the items in the factor analysis.

To test this hypothesis, we conducted a preliminary analysis, dividing the sample in two parts, according to age. We observed that, for the participants of up to 40 years in age, these items were related to scores for both Self-control and Expressivity. Thus, this explanatory hypothesis seems to be relevant, although it should be tested more thoroughly in future studies.

Another possible explanation could be cultural differences that could have caused a different understanding of the items. For example, while Brazilian couples may deal with difficult situations by making an effort to control negative emotions, (Self-control), Portuguese couples may try to resolve differences by expressing positive emotions (Expressivity), and empathic social skills, to understand the partner's point of view. Furthermore, the correlation between these dimensions $(r=0.61)$ is understandable in the context of a marital relationship, given that selfcontrol implies observing and interpreting the spouse in order to self-regulate. In this manner, empathy is closely intertwined with this process. It will be important, however, to further investigate the hypothesis about the use of empathic social skills among Portuguese couples, during conflict resolution.

Overall, the results demonstrated good internal consistency for the first three dimensions. The fourth dimension, however, yielded a lower score $(\alpha=0.55)$ that, although similar to the one found by Villa and Del Prette, Z. A. P. (2012) in the Brazilian sample $(\alpha=0.57)$, is considered poor by George and Mallery (2003). However, it is true that the number of items directly effects alpha values; as such, Clark and Watson (1995) recommend constructing instruments with at least four items for each dimension. Thus, the fact that the Assertive Conversation dimension has only two items may be contributing to the low value for this coefficient. Additional studies are needed to assess the relevance of this dimension and, if theoretical models and empirical evidence support its inclusion in the inventory, new items will need to be tested, to improve the measurement precision of this dimension.

According to Marôco (2014), precision is a necessary, but not sufficient, indicator of the validity of an instrument. In addition, it is important to examine the coherence between the internal structure of the instrument and theoretical concepts regarding the phenomenon. As such, Pasquali (2010) emphasizes the role of factor analysis, which makes it possible to determine when a theoretical model is coherent with an evidence-based factor structure, indicating the validity of the theoretical model. However, the validation of a construct requires the examination of these and of other types of evidence (Nunes \& Primi, 2010). Thus, in addition to the evidence reported in this paper concerning the precision and validity of the Portuguese version of the Marital Social-Skills Inventory, convergent and discriminatory validity tests, for example, are needed, to make further progress in validating this instrument (Urbina, 2007). As such, in future studies, the factor structure presented in this paper should be further tested and additional information is needed to evaluate its adequacy for the Portuguese population.

It is also important to consider some of the limitations of the current study that may involve factors that can account for differences in the Brazilian and Portuguese factor structures, such as differences in the educational levels of the Portuguese and Brazilian respondents. While $46.8 \%$ of the Brazilian participants had completed high school (equivalent to grade 12, in Portugal) or had initiated undergraduate studies, in the current study, only $29.8 \%$ of the participants had this same educational level, while $39.8 \%$ had or were working on a graduate degree. Expectations for social behavior vary in relation to a person's 
sociodemographic characteristics (especially gender, age and profession), but also vary according to the cultural context (Del Prette et al., 2004). We also emphasize that a non-random, convenience sample was used, which is a limiting factor on the results. Furthermore, no instruments were used to evaluate the relationship between marital social-skills and other constructs, such as marital satisfaction.

It is important to highlight that, although there are cultural similarities between Portugal and Brazil, given the historical influences they have in common, there are also cultural influences that are specific to each country. Situational and cultural factors have a significant influence on social skills and need to be identified, given that they are not fixed; social performance alters according to contextual cues, social demands and conduct patterns that are typical of each culture and subculture (Del Prette et al., 2004). As such, the transcultural adaptation and validation of social skills inventories must always take into consideration the existence of cultural specificities that may make it difficult to produce a second version of the instrument that is the same as the original one. In the current study, more general transcultural elements that could be valid for both contexts were identified.

In conclusion, we believe that the psychometric analyses and the initial evidence for the validity of the HSC-Villa \& Del-Prette, presented in this study, point to the possibility of using this instrument not only for the clinical evaluation of social skills repertoires, but also in a more general context of marital psychotherapy and intervention programs. In addition to intervention programs for couples, in the clinical field, the IHSC-Villa \& Del-Prette could also be used to investigate other aspects of conjugality, such as studies on marital satisfaction, empathy, and quality of communication between the spouses.

\section{Acknowledgments}

The first author wishes to thank Coordenação de Aperfeiçoamento de Pessoal de Nível Superior for the research scholarship she received, that enabled her to conduct this research.

\section{Contributors}

J.C.S. AGUIAR was responsible for the conception of this research, data collection, data analysis and interpretation of the results; the M. MATIAS, E.J. BARHAM, A.M.G.V. FONTAINE, and Z.A.P. DEL PRETTE contributed to the discussion, revision and approval of the final version of this manuscript.

\section{References}

Arbuckle, J. L. (2012). IBM ${ }^{\circledR}$ SPSS $^{\circledR}$ Amos $^{\mathrm{TM}} 21$ user's guide. [On-line]. Retrieved March 10, 2016, from $\mathrm{ftp}: / /$ public.dhe.ibm.com/software-/analytics/spss/ documentation/ amos/21.0/en/Manuals/IBM_SPSS_ Amos_Users_Guide.pdf

Bolsoni-Silva, A.T., \& Marturano, E. M. (2010). Procedimentos de avaliação em terapia de casais a partir de múltiplos instrumentos. Temas em Psicologia, 18(1), 31-44. Recuperado em janeiro 30, 2016, de http://hdl.handle.net/-11449/134557

Braz, A. C., Comodo, C. N., Del Prette, Z. A. P., Del Prette, A., \& Fontaine, A. M. (2013). Habilidades sociales e intergeneracionalidad en las relaciones familiares. Apuntes de Psicología, 31(1), 77-84. Recuperado en marzo 18, 2016, de http://apuntesdepsicologia.es/ index.php/revista/article/view/305

Capafóns, J. I., \& Sosa, C. D. (2015). Relaciones de pareja e habilidades sociales: el respeto interpersonal. Behavioral Psychology/Psicología Conductual, 23(1), 25-34. Recuperado en septiembre 20, 2016, de https://-dialnet.unirioja.es/servlet/articulo?-codigo= 5186107

Clark, L. A., \& Watson, D. (1995). Constructing validity: Basic issues in scale development. Psychological Assessment, 7(3), 309-319. http://dx.doi.org/10.103 7/-10403590.7.3.309

Couto, G., Vandenberghe, L., Tavares, W. M., \& Silva, R. L. F. C. (2012). Interações e habilidades sociais entre universitários: um estudo correlacional. Estudos de Psicologia (Campinas), 29(Supl.), 667S-677S. http:// dx.doi.org/10.1590/S0103-166X2012000500003

Del Prette, A., \& Del Prette, Z. A. P. (2014). Psicologia das relações interpessoais e habilidades sociais: vivências para o trabalho em grupo (11a. ed.). Petrópolis: Vozes.

Del Prette, Z. A. P., Del Prette, A., Barreto, M. C., Bandeira, M., Rios-Saldaña, M., Ulian, A. L., ... Villa, M. B. (2004). Habilidades sociais de estudantes de Psicologia: um estudo multicêntrico. Psicologia: Reflexão e Crítica 17(3), 341-350. Recuperado em mar-ço 30, 2016, de http://www.redalyc.org/-articulo.oa?id= 18817307

Féres-Carneiro, T., \& Neto, O. D. (2010). Construção e dissolução da conjugalidade: padrões relacionais. 
Paidéia, 20(46), 269-278. http://dx.doi.org/10.1590/ S0103863X2010000200014

Figueredo, P. M. V. (2005). A influência do locus de controle conjugal, das habilidades sociais conjugais e da comunicação na satisfação com o casamento. Ciências e Cognição, 6(1), 123-132. Recuperado em setembro 29, 2016, de http://www.cienciasecognicao. org/revista/index.php/cec/-article/view/539

George, D., \& Mallery, P. (2003). SPSS for Windows step by step: A simple guide and reference, 11.0 update (4th ed.). Boston: Allyn and Bacon.

Gottman, J., \& Rushe, R. (1995). Communication and social skills approaches to treating ailing marriages: A recommendation for a new marital therapy called "Minimal Marital Therapy". In W. O'Donohue \& L. Krasner (Eds.), Handbook of psychological skills training: Clinical techniques and applications. Boston: Allyn and Bacon.

Kline, R. B. (2011). Principles and practice of structural equation modeling (3rd ed.). New York: Guilford Press.

Manolio, C. L., \& Ferreira, B. C. (2011). O campo das habilidades sociais no Brasil: entrevista com Almir e Zilda Del Prette. Estudos e Pesquisas em Psicologia, 11(2), 537-550. http://dx.doi.org/10.12957/epp.2011. 8393

Marôco, J. (2014) Análise estatística com utilização do SPSS (6a. ed.). Lisboa: Report Number.

Norgren, M. B. P., Souza, R. M., Kaslow, F., Hammerschmidt, H., \& Sharlin, S. A. (2004). Satisfação conjugal em casamentos de longa duração: uma construção possível. Estudos de Psicologia (Natal), 9(3), 575-584. http:// dx.doi.org/10.1590/S1413294X2004-000300020

Nunes, C. H. S. S., \& Primi, R. (2010). Aspectos técnicos e conceituais da ficha de avaliação dos testes psicológicos. In A. A. A. Santos (Ed.), Avaliação psicológica: diretrizes na regulamentação da profissão. Brasília: CFP.
Pasquali, L. (2010). Instrumentação psicológica: fundamentos e prática. Porto Alegre: Artmed.

Pinho, V. D., Fernandes, C. S., \& Falcone, E. M. O. (2011). A influência da idade e da escolaridade sobre a experiência empática de adultos. Estudos e Pesquisas em Psicologia, 11(2), 456-471. http://dx.doi. org/10.12957/epp.2011.8384

Sardinha, A., Falcone, E. M. O., \& Ferreira, M. C. (2009). As relações entre a satisfação conjugal e as habilidades sociais percebidas no cônjuge. Psicologia: Teoria e Pesquisa, 25(3), 356-402. http://dx.doi.org/10.1590/ S010237722-009000300013

Tabachnick, B. G., \& Fidell, L. S. (2013). Using multivariate statistics (6th ed.). New York: Allyn and Bacon.

Tanzer, N. K., \& Sim, C. Q. E. (1999). Adapting instruments for use in multiple languages and cultures: A review of the ITC guidelines for test adaptations. European Journal of Psychological Assessment, 15(3), 258-269. http://dx.doi.org/10.1027-/1015-5759.15.3.258

Urbina, S. (2007). Fundamentos da testagem psicológica. Porto Alegre: Artmed.

Villa, M. B. (2005). Habilidades sociais no casamento: avaliação e contribuição para a satisfação conjugal (Tese de doutorado não-publicada). Universidade de São Paulo.

Villa, M. B., \& Del Prette, Z. A. P. (2012). Inventário de Habilidades Sociais Conjugais (IHSC-Villa\&Del-Prette): manual de aplicação, apuração e interpretação. São Paulo: Casa do Psicólogo.

Villa, M. B., Del Prette, Z. A. P., \& Del Prette, A. (2007). Habilidades sociais conjugais e filiação religiosa: um estudo descritivo. Psicologia em Estudo, 12(1), 23-32. http://dx.doi.org/10.1590/S141373722007000100 004

Received: May 2, 2016

Final version: February 19, 2017

Approved: March 2, 2017 